\title{
The relationship between learning strategies and learning interest against student learning outcomes at state elemetary
}

\author{
Zainar Zainar ${ }^{1}$, Happy Fitria ${ }^{2}$, Syaiful Eddy ${ }^{2}$ \\ ${ }^{1}$ Sekolah Dasar Negeri 2 Setia Jaya, Indonesia \\ ${ }^{2}$ Universitas PGRI Palembang, Indonesia
}

\begin{tabular}{l} 
Article Info \\
\hline Article history: \\
Received Jul $12^{\text {th }}, 2021$ \\
Revised Aug $7^{\text {th }}, 2021$ \\
Accepted Aug $30^{\text {th }}, 2021$ \\
\hline
\end{tabular}

\section{Keyword:}

Learning strategies Interest in learning Learning outcomes

\begin{abstract}
This study aims to analyze and describe :1) the relationship between Learning Strategies and Student Learning Outcomes, 2) the relationship between Learning Interest and Student Learning Outcomes, 3) the relationship between Learning Strategies and Learning Interests on Student Learning Outcomes. The results stated: 1) there is a relationship between learning strategies and student learning outcomes; 2) there is a relationship between interest in learning and student learning outcomes; and 3) there is a relationship between learning strategies and interest in learning towards student learning outcomes.
\end{abstract}

\section{Corresponding Author:}

(C) 2021The Authors. Published by IICET.

Zainar, Z.,

Sekolah Dasar Negeri 2 Setia Jaya, Indonesia

Email: zainar356@gmail.com

\section{Introduction}

Teachers who have been the only major role in providing scientific education services will be gradually displaced along with the times. In order to remain needed and meaningful in their presence in the classroom. Therefore, teachers must always be required to innovate and have creativity as needed, especially in learning strategies in the classroom. In line with the opinion of [1], teachers in the education process play a very important role. The teacher as the leader and person in charge of class management greatly determines the quality of learning. The creativity of a teacher must be able to change teaching and learning strategies to be more meaningful and able to develop all dimensions such as character, personality, intellectual, emotional and social students. Also added by the opinion of [2] that teachers are not only educating, but also teaching and training. Teachers are required to have good abilities and competencies so that their duties and responsibilities can be carried out well too.

In addition, teachers are a component of education that plays a very important role in efforts to form potential human resources in the field of development. Therefore, teachers are an element of education that must participate actively in placing their position as professionals. As stated by [3], the world of education that produces human resources is demanded how to produce human resources who are ready for this development. Human resources have a major role in achieving goals or success and for the continuity of development in this modern era. 
This is in line with the opinion of [4] that basically there are various factors that affect the success of education, including teachers, students, facilities and infrastructure, educational environment, curriculum. Of these several factors, in the activities of the learning process in schools the teacher occupies a very important position and without neglecting other supporting factors, the teacher is also the subject of education that determines the success of education itself, so it must be admitted that teachers are the main factor in the educational process Even though the educational facilities at school are complete and sophisticated, if it is not supported by the existence of qualified teachers, it is impossible to obtain and or lead to a maximum learning and learning process.

The learning strategy is a presentation technique that teachers must have to teach students with the aim of the lessons being delivered that can be easily understood by students. One of the efforts that teachers can make to increase student learning activeness and creativity is to foster a sense of interest in students in learning. According to [5] states that students' interest in learning can be expressed through statements that they prefer something over others, active participation in learning activities, and give greater attention to something they are interested in regardless of others (focus). In line with that to increase student interest, teachers are required to make more innovative lessons that can encourage students to learn more optimally, both independently and in classroom learning with innovative methods, teaching aids and other learning media [6].

Based on observations of teachers at SD Negeri 1 Jirak, SD Negeri 2 Setia Jaya, and SD Negeri Bangkit Jaya, the teacher's teaching strategy is still not in accordance with the needs of students. Teachers are still focused on using textbooks in delivering learning material, while students need to be given more interesting learning methods and media. In addition, students showed a lack of student interest in the material presented by the teacher in the classroom, there were some students who were late for class hours, students tended to feel bored with monotonous learning strategies.

Learning outcomes are something that is achieved and obtained by students after going through the learning process thanks to their efforts or thoughts which are expressed in the form of mastery, basic skills, and skills towards knowledge obtained from the teaching and learning process. The quality of student learning outcomes can be expressed in the form of an assessment of attitudes, knowledge and basic skills achieved. The learning outcomes of these students will be of high quality if the learning outcomes with the final result are grades that meet the assessment standards set by the school. In line with the opinion of [7] the success of implementing learning in schools must be evaluated thoroughly, including by evaluating the quality of the process and learning outcomes. Overall understanding of the basic concepts of learning will not be perfect if it stops at the definition or process. Basically, the learning process is characterized by changes in overall behavior involving cognitive, affective, and psychomotor aspects. Added by [8] that the quality of good education is a benchmark for the success of the performance shown by teachers. Where, one example of the success of a teacher's performance is reflected in the learning outcomes obtained by students.

Based on the above background, the researcher will examine this problem by conducting a study entitled "The Relationship Between Learning Strategies and Learning Interest Against Student Learning Outcomes at SD Negeri Jirak Jaya". The objectives of this study are as follows: 1) To analyze and describe the relationship between Learning Strategies and Student Learning Outcomes of SD Negeri Jirak Jaya, 2) To analyze and describe the relationship between Learning Interest and Student Learning Outcomes of SD Negeri Jirak Jaya , 3) To analyze and describe the relationship between Learning Strategies and Learning Interests on Student Learning Outcomes of SD Negeri Jirak Jaya.

\section{Method}

This study uses a quantitative descriptively, which is a number that indicates the direction and strength of the relationship between two variables independent together with one or more variable dependent. [9] states that the quantitative approach is the approach used by researchers in research by measuring variable indicators, so that an overview and conclusions of the research problem can be obtained [8]. The population in this study were all SD Negeri Jirak Jaya, especially students in grade V, amounting to 17 State SD consisting of 2 State SD with Accreditation A, 12 State SD with Accreditation B, and 12 State SD with C Accreditation as many as 3 State SD.

The total sample taken was 72 students, especially students in grade V from 3 State Elementary Schools consisting of SD Negeri 1 Jirak with 37 students consisting of 24 male students and 13 female students, SD Negeri 2 Setia Jaya with the number of students. 24 students consisting of 11 male students and 13 female students, and SD Negeri Bangkit Jaya with 11 students consisting of 6 male students and 6 female students. The reason for taking the sample unit is limited to that number, because to obtain school 
characteristics based on the results of Accreditation A, B and C that represent the population of each school. Data were collected using a Likert scale model questionnaire. The data analysis technique used 1) descriptive quantitative analysis technique; and 2) multiple regressions.

\section{Results and Discussions}

\section{The Relationship of Learning Strategies to Student Learning Outcomes}

Results of the study showed that the Learning Strategy (X1) to the Student Learning Outcomes (Y) after analysis of data obtained by value $t$ arithmetic (6.444) $>t$ table (1.99) at the significant level of $5 \%$ and a probability value $(\mathrm{p})$ of $0.000<0,05$. From these results it can be concluded that there is a significant relationship between Learning Strategy (X1) and Student Learning Outcomes (Y) in SD Negeri Jirak Jaya. From this statement it can be said that Ho is rejected and Ha is accepted. In addition, it also explains the percentage of the relationship between Learning Strategy (X1) and Student Learning Outcomes (Y) which is called the coefficient of determination which is the result of squaring R.From the table above, it is obtained the coefficient of determination (Adjust R Square) of 0.363 which implies that the relationship of Learning Strategies (X1) to Student Learning Outcomes (Y) amounted to $36.3 \%$; while the remaining $63.7 \%$ is influenced by other variables not examined in this study.

The findings of this study are in line with the results of research by [10]. The results of this study show that the principal's strategy in developing professional competence is that teachers are assigned to take part in education \& training, both those carried out by the school institution itself and by other educational institutions. Then the teacher is asked to train and develop himself related to his job or position such as discipline, discussion and motivation. In addition, the principal also completes school infrastructure. According to [11] learning strategies are strategies used in learning, such as discussion, observation and question and answer, and other activities that can encourage the formation of student competencies. In learning, the main task of the teacher is to condition the environment in order to support behavior change for students. The concepts become integrated in one activity when there is an interaction between teachers and students who are both active in learning.

\section{Relationship between Learning Interests and Student Learning Outcomes}

Results of the study showed that the Interest in Learning (X2) on Student Learning Outcomes (Y) after analysis of data obtained by value $t$ arithmetic (8.929) $>t$ table (1.99) at the significant level of $5 \%$ and a probability value $(p)$ of $0.000<0$, 05. From these results it can be concluded that there is a significant relationship between Learning Interest (X2) and Student Learning Outcomes (Y) at SD Negeri Jirak Jaya. From this statement it can be said that Ho is rejected and $\mathrm{Ha}$ is accepted. In addition, it also explains the percentage of the relationship between Learning Interest (X2) and Student Learning Outcomes (Y) which is called the coefficient of determination which is the result of squaring R.From the table above, it is obtained the coefficient of determination (Adjust R Square ) of 0.526 which implies that the relationship of Learning Interest (X2) to Student Learning Outcomes (Y) is 52.6\%; while the remaining 47.4\% is influenced by other variables not examined in this study.

The findings of this study are in line with the results of research by [12]. The results of this study indicate that: (1) there is a significant relationship between learning strategies and student learning outcomes, (2) there is an insignificant relationship between student learning interest and student learning outcomes, because there are many factors such as the number of students in the class and the number of subjects, so that teachers find it difficult to arouse student interest in learning, (3) there is an insignificant interaction relationship between learning strategies and interest in learning towards student learning outcomes, because student interest in learning is mediocre due to several factors such as inadequate facilities, teacher attention, parental attention or less interested material. According to [13] what is meant by interest in learning is a feeling of preference and interest in something or activity, without being asked. Interest in learning is basically the acceptance of a relationship between oneself and something outside oneself. The stronger the relationship, the greater the interest in learning one has.

\section{The Relationship between Learning Strategies and Learning Interests on Student Learning Outcomes}

The results showed that the Learning Strategy (X1) and Learning Interest (X2) on Student Learning Outcomes (Y) after the data analysis was carried out, the calculated $\mathrm{F}$ value (14.431) $>\mathrm{F}$ table (3.13) was obtained . Then the significance test obtained the value of Sig $=0.000<0.05$. Hypothesis 3 test results can be concluded that there is a significant relationship together Learning Strategy (X1) and Learning Interest (X2) on Student Learning Outcomes (Y). In addition, it also explains the percentage of the relationship between the independent variables (Learning Strategies and Learning Interests) on the dependent variable (Student 
Learning Outcomes) which is called the coefficient of determination which is the result of squaring R.From the table above, the coefficient of determination (Adjust R Square) is obtained of 0.520 which implies that the relationship of the independent variables (Learning Strategies and Learning Interests) to the dependent variable (Student Learning Outcomes) is $52 \%$; while the remaining $48 \%$ is influenced by other variables not examined in this study.

According to [14] providing an understanding of learning outcomes is a change in behavior in a person that can be observed and measured in the form of knowledge, attitudes and skills. This change can be interpreted as the occurrence of improvement and development that is better than before and those who don't know become know. In line with [15] opinion, learning outcomes indicate the actual ability of students who have experienced the process of transferring knowledge from someone who can be said to be mature or have less knowledge.

Furthermore, the results of research by [16]. The results of this study show that the strategy of the head of SMK Negeri 2 Bukittinggi in implementing the National Education Standards (SNP) varies according to each standard. In implementing content standards, a curriculum development team was formed to collaborate with the business world in developing curriculum.

\section{Conclusions}

Based on the results of data analysis, it can be concluded as follows: 1) there is a relationship of learning strategies to student learning outcomes; 2) there is a relationship between interest in learning and student learning outcomes; and 3) there is a correlation learning strategies and interest in learning the learning outcomes of students with an F arithmetic (14.431)> F table (3.13) as well as the significant value of 0.000 $<0.05 \mathrm{Ho}$ is rejected and $\mathrm{Ha}$ accepted shown by the regression line $\mathrm{Y}=11.031+0.653 \mathrm{X} 1+$ $0.702 \mathrm{X} 2$. Learning Strategies (X1) and Learning Interest (X2) are able to influence Student Learning Outcomes (Y) by $52 \%$; while the remaining $48 \%$ is influenced by other variables not examined in this study.

\section{References}

Arikunto, S. (2013). Prosedur Penelitian Suatu Pendekatan Praktik. Jakarta: Rineka Cipta.

Dahlan, M, Arafat, Y., dan Eddy, S. (2020). Pengaruh Budaya Sekolah dan Diklat terhadap Kinerja Guru. Journal of Education Research, 1(3), 2020, Pages 218-225.

Djamarah, S. B., dan Zain, A. (2012). Strategi Belajar Mengajar. Jakarta: Rineka Cipta.

Fitria, H, Aprida, Y., Nurkhalis. (2020). Pengaruh Supervisi Kepala Sekolah dan Motivasi Kerja Guru Terhadap Kinerja Guru. Journal of Education Research, 1(2), 2020, Pages 160-164.

Fitria, H., Subekti, H.A, Nubaiti, Masilawati. (2020). Pemanfaatan Video Conference Sebagai Media Permbelajaran Interaktif Pada Mata Pelajaran Produktif Di Sekolah Menengah Kejuruan. Seminar Nasional Pendidikan PPS Universitas PGRI Palembang 2020. Jurnal Prosiding Seminar Nasional, Pendidikan Program Pascasarjana Universitas PGRI Palembang 10 Januari 2020.

Fitria, H, Widayati, F., Fitriani, Y. (2020). Pengaruh Kepuasan Kerja dan Loyalitas Kerja terhadap Kinerja Guru. Journal of Education Research, 1(3), 2020, Pages 251-257.

Fitria, H, Marliya, Nurkhalis. (2020). Pengaruh Sarana Prasarana dan Lingkungan Kerja terhadap Kinerja Guru Di SMP Negeri se-Kecamatan Prabumulih Barat. Journal of Education Research, 1(3), 2020, Pages 206-212.

Firmansyah, D. (2015). Hubungan Strategi Pembelajaran dan Minat Belajar Terhadap Hasil Belajar Matematika. Jurnal Online. Dosen Prodi Pendidikan Matematika. FKIP. Universitas Singaperbangsa Karawang. Jurnal Pendidikan Unsika. ISSN 2338-2996. Volume 3 Nomor 1, Maret 2015.

Hamalik, O. (2013). Proses Belajar Mengajar. Jakarta: Bumi Aksara.

Mulyasa. (2014). Menjadi Guru Profesional: Menciptakan Pembelajaran Kreatif dan Menyenangkan. Bandung: Rosdakarya.

Nasional Pendidikan (SNP) Pada SMK Negeri 2 Bukittinggi. Jurnal Manajemen, Kepemimpinan, dan Supervisi Pendidikan (JMKSP). Volume 4, No. 1, Januari-Juni 2019.

Nurhayati, Arafat, Y., Fitriani, Y. (2020). Penggunaan Media Power Point Dalam Pembelajaran Matematika Dan Pengaruhnya Terhadap Prestasi Belajar Siswa. Jurnal Ilmiah Bina Edukasi. ISSN 1979-8598E. ISSN: 2655-8378 Vol. 13, No. 1, Juni 2020, 75-87.

Purwanto. (2010). Evaluasi Hasil Belajar. Yogyakarta: Pustaka Belajar. 
Sianturi, R., Lian, B., dan Puspitasari, A. (2020). Strategi Kepala Sekolah dalam Mengembangkan Kompetensi Profesional Guru. Jurnal Pendidikan Tambusai. SSN: 2614-6754 (print) ISSN: 2614-3097 (Online) Halaman 1836-1839 Volume 4 Nomor 3 Tahun 2020.

Sriwahyuni, E., dan Kristiawan, M. (2019). Strategi Kepala Sekolah Dalam Mengimplementasikan Standa Slameto. (2013). Belajar dan Faktor-Faktor yang Mempengaruhinya. Jakarta: Rhineka Cipta.

Suratman, Arafat, Y., dan Eddy, S. (2020). Pengaruh Kepemimpinan Kepala Sekolah dan Kompetensi Guru Terhadap Kinerja Guru di Indonesia. Jurnal Pekerjaan Sosial dan Pendidikan Sains. Jilid 1 (2) 2020. EISSN: 2723 6919, Hal. 96-104. 